\title{
ANTICANCER POTENCY OF COPPER(I) COMPLEXES AGAINST A RANGE CANCER CELL LINES: A REVIEW
}

\author{
Narendra Kumar Singh ${ }^{1}$, Paras Nath Yadav ${ }^{2 *}$ \\ ${ }^{I}$ Department of Chemistry, Amrit Campus, Tribhuvan University, Kathmandu, Nepal \\ ${ }^{2}$ Central Department of Chemistry, Tribhuvan University, Kirtipur, Kathmandu, Nepal \\ "Corresponding author: pnyadav219@gmail.com
}

(Received: March 01, 2021; Revised: May 26, 2021; Accepted: June 04, 2021)

\begin{abstract}
The copper(I) complexes of N,N-diimine, N,O- and/or N,S- bidentate systems perform significant dose-dependent anticancer activity toward various cell lines viz. MCF-7, LNCap, PSN-1, A431, BxPC3, H157, A2780, HeLa, MDAMB231, MGC-803 etc. The copper(I) complexes can cross the cellular plasmalemma that results in the accumulation of copper ion in the cancer cells, exhibit significant anticancer effect and overcome the multidrug resistance because these can slightly induce the DNA cleavage as a result of limited generation of reactive oxygen species (ROS). Copper(I) complexes exhibit significantly higher broad-spectrum antiproliferation and cell apoptosis via mitochondrial pathway than that of their corresponding $\mathrm{Cu}(\mathrm{II}), \mathrm{Co}(\mathrm{II}), \mathrm{Pd}(\mathrm{II})$, and $\mathrm{Ni}(\mathrm{II})$ complexes. The copper(I) complexes inhibit the cancer cells not only via ROS generation but also via DNA interactions possibly by attacking the sugar-phosphate backbone of DNA due to their oxidative and partial dissociation behavior. Copper(II/I) complexes are also able to cleave DNA by hydrolytic pathway and induce caspase-dependent-mitochondrial-mediated cell apoptosis by ROS production or blocking the progression of cell cycles. In many cases, the modification in organic moiety and the placement of electronegative substituent near the metallic center of complexes have been found to enhance their anticancer potency in a significant manner. Thus, copper(I) complexes may be used as the better anticancer drugs with multiple modes of action compared to the copper(II) complexes due to having oxidative behavior and generation of empty site on copper(I) ion during partial dissociation.
\end{abstract}

Keywords: Antibiotics, Anticancer activity, Cisplatin, Copper(I) complex, Diphosphane.

\section{INTRODUCTION}

An essential trace element copper act as catalytic and structural cofactors and have importance in human life because of its nature of accumulation in the tumor cells due to their selective permeability and its key role in DNA synthesis, enzymatic functions, intracellular redox potential regulation (Daniel et al., 2005; Lopes et al., 2017; Singh et al., 2020). In the serum of living organisms, $\mathrm{Cu}(\mathrm{I})$ and $\mathrm{Cu}(\mathrm{II})$ bind to ceruloplasmin and generate the active center in metalloproteins (Lopes et al., 2017; Singh et al., 2020). The redox behavior of copper $\left(\mathrm{Cu}^{\mathrm{I} / \mathrm{II}}\right)$ plays an important role to provoke anticancer potency, diminish the toxicity, and overcome the resistance activity of the drug (Gunasekaran et al., 2011, Gandin et al., 2015; Singh et al., 2020).

Many copper complexes have been found to exhibit anticancer activities for example copper(II) complex of 5nitroisatin-4-(1-(2-pyridyl)piperazinyl)-3-

thiosemicarbazone exhibited better anticancer potency toward breast cancer cell, MDA-MB-231 ( $\left.\mathrm{IC}_{50} 0.85 \mu \mathrm{M}\right)$ (Singh et al., 2021a). Copper complexes have been found to perform different anticancer mechanism of action than that of platinum complex (cisplatin) for example casiopeins has been found to exhibit high antineoplastic activity by respiratory inhibition and ATP synthesis (Marin-Hernandez et al., 2003). Copper complexes of many ligands such as acetyl pyridine, dipyridyl ketone, acetyl pyrazine, etc. have high potency of cancer cell inhibition due to their interaction with DNA either by the covalent or noncovalent way (Miller III et al., 1999; Jansson et al., 2010).

The thiocarbamides with two different substituents on $\mathrm{N}$ atoms exhibit hydrogen bonding between the carbonyl group of substituent and HN group of amide that helps the existence of coordinate covalent bond directly through Satoms, increases lipophilicity and anticancer potency of ligands and their complexes via effective interaction with DNA (Xian et al., 2004; Saeed et al., 2010; Singh et al., 2015; Saswati et al., 2015; Mahendiran et al., 2018b; Pandey et al., 2018). Copper(I) ion, obtained by the reduction of copper(II) ion with metallo-reductase at the cell surface of living organisms, before uptake into the cell can be transported into the living cells by their specific transporters (Puig \& Thiele 2002; Puig et al., 2002; Marzano et al., 2009). Copper(I) ion tends to undergo oxidation to form copper(II) ion so there is difficulty in stabilizing the copper(I) complexes. That's why copper chemistry has been dominated by copper(II) complexes. Copper(I) ion with $3 \mathrm{~d}^{10}$ configuration has been stabilized by phosphane molecule due to having soft base $\mathrm{P}$-atom and $\mathrm{N}, \mathrm{N}$-diimine systems and it performed significant cytotoxic activity against various cancer cell lines (Santini et al., 2013; Gandin et al., 2017; Lopes et 
al., 2017; Bravo et al., 2019). Copper(I) complexes dissociate partially by generating an empty site on $\mathrm{Cu}^{+}$ ions that can facilitate the complexes to interact with the biological target (Santini et al., 2013). The modification in the structure of organic moiety by different substituents affects the anticancer activity of copper complexes (Saswati et al., 2015; Mahendiran et al., 2018b; Singh et al., 2021b).

Having a tendency to transport into living cells by specific transporters, different anticancer mechanism, oxidative behavior, and ability to generate an empty site by partial dissociation made copper(I) complexes better anticancer agents than $\mathrm{Cu}(\mathrm{II}), \mathrm{Zn}(\mathrm{II}), \mathrm{Pd}(\mathrm{II})$, etc complexes. Thus the study of copper(I) complexes with different modifications in aromatic moiety will be a milestone in the field of pharmaceutical research.

\section{Copper(I) complexes as anticancer agents}

\section{Pyridinyl copper(I) complexes}

The copper(I) complexes of imine ligands viz. (E)-2((pyridin-2-ylmethylene)amino)phenol $\left(\mathrm{C}_{1}-\mathrm{C}_{4}\right), \quad(\mathrm{E})-4-$ methyl-2-((pyridin2-ylmethylene)amino)phenol $\left(\mathrm{C}_{5}-\mathrm{C}_{6}\right)$, and (E)-4-((Pyridin-2-ylmethylene)amino)phenol $\left(\mathrm{C}_{7}\right)$ (Fig. 1) against human glioblastoma (U87) cell showed remarkable anticancer potency at micromolar concentration $\left(\mathrm{IC}_{50} 20-46.7 \mu \mathrm{M}\right.$ ). The order of complexes toward cytotoxic activity: $\mathrm{C}_{3}>\mathrm{C}_{7}>\mathrm{C}_{2}>\mathrm{C}_{6}>\mathrm{C}_{1}>\mathrm{C}_{5}>\mathrm{C}_{4}$ confirmed that the copper(I) complexes with halide ions performed higher anticancer potency than that with isothiocyanate $\left(\mathrm{NCS}^{-}\right)$ion and the effect of anticancer potency also increased with the increasing mass of halide ions. The complexes showed inhibition toward growth, migration ability, cell cycle progression, and expression level of anti-apoptotic genes but induced necrosis, the expression level of apoptotic genes, and apoptosis in a dose-dependent manner (Milani et al., 2020).

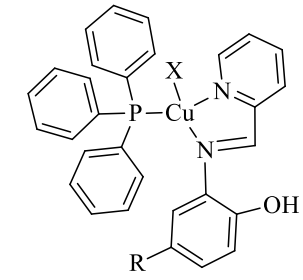

$\mathrm{C}_{1}\left(\mathrm{R}=\mathrm{H}, \mathrm{X}=\mathrm{Cl}^{-}\right), \mathrm{C}_{2}\left(\mathrm{R}=\mathrm{H}, \mathrm{X}=\mathrm{Br}^{-}\right)$,

$\mathrm{C}_{3}\left(\mathrm{R}=\mathrm{H}, \mathrm{X}=\mathrm{I}^{-}\right), \mathrm{C}_{4}\left(\mathrm{R}=\mathrm{H}, \mathrm{X}=\mathrm{NCS}^{-}\right)$,

$\mathrm{C}_{5}\left(\mathrm{R}=\mathrm{CH}_{3}, \mathrm{X}=\mathrm{Cl}^{-}\right), \mathrm{C}_{6}\left(\mathrm{R}=\mathrm{CH}_{3}, \mathrm{X}=\mathrm{Br}^{-}\right)$

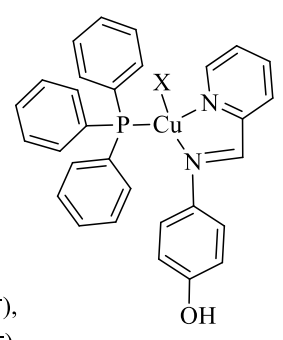

$\mathrm{C}_{7}$

Fig. 1. Copper(I) complexes of ((Pyridin-2ylmethylene)amino)phenol and it's derivative (Milani et al., 2020)

\section{Diphosphane and bidentate N, O-heteroaromatic $\mathrm{Cu}(\mathrm{I})$ complexes}

The in vitro cytotoxic study of copper(I) complexes of mixed ligands viz. diphosphane (PP) and an N, O-

heteroaromatic bidentate ligand $(\mathrm{LL}),[\mathrm{Cu}(\mathrm{PP})(\mathrm{LL})]\left[\mathrm{BF}_{4}\right]$ $\left(\mathrm{C}_{8}-\mathrm{C}_{25}\right)$ (Fig. 2) against cancer cell lines MCF-7 (breast cancer), LNCap (human prostate cancer) and normal prostate cell line (RWPE) exhibited anticancer activity but showed significant activity toward LNCap $\left(\mathrm{IC}_{50}\right.$ 0.20-1.96 $\mu \mathrm{M})$.

$$
\begin{aligned}
& \left.\left[\because-\mathrm{P}>\mathrm{Cu}-\frac{\mathrm{L}}{\mathrm{P}}\right)\right] \mathrm{BF}_{4} \\
& \mathrm{C}_{8}-\mathrm{C}_{25}
\end{aligned}
$$

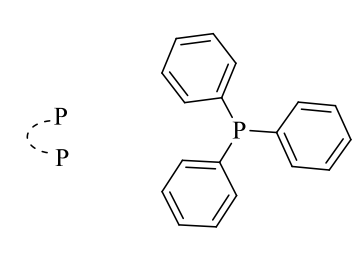

$\mathrm{PPh}_{3}$<smiles>COc1ccc(P(c2ccc(OC)cc2)c2ccc(OC)cc2)cc1</smiles>

pMPP<smiles>O=C(c1ccccc1)c1ccccn1</smiles>

bopy

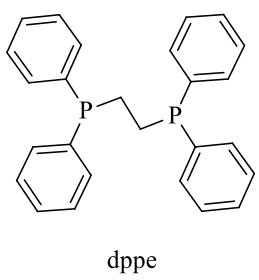<smiles>CC(=O)c1ccccn1</smiles><smiles>CC(=O)c1cnccn1</smiles><smiles>O=C(c1ccccc1)c1nccc2ccccc12</smiles>

$\mathrm{C}_{8}(\mathrm{PP}=2 m$ TPPMS, $\mathrm{LL}=2 \mathrm{NCMe})$,

$\mathrm{C}_{9}(\mathrm{PP}=2 p \mathrm{MPP}, \mathrm{LL}=2 \mathrm{NCMe})$,

$\mathrm{C}_{10}\left(\mathrm{PP}=2 \mathrm{PPh}_{3}, \mathrm{LL}=\right.$ bopy $), \mathrm{C}_{11}\left(\mathrm{PP}=2 \mathrm{PPh}_{3}, \mathrm{LL}=2\right.$-ap $)$,

$\mathrm{C}_{12}\left(\mathrm{PP}=2 \mathrm{PPh}_{3}, \mathrm{LL}=2-\mathrm{apz}\right), \mathrm{C}_{13}\left(\mathrm{PP}=2 \mathrm{PPh}_{3}, \mathrm{LL}=\right.$ isoquinpk $)$,

$\mathrm{C}_{14}(\mathrm{PP}=2 m$ TPPMS, LL=bopy $), \mathrm{C}_{15}(\mathrm{PP}=2 m$ TPPMS, LL=2-ap $)$,

$\mathrm{C}_{16}(\mathrm{PP}=2 m$ TPPMS, LL=2-apz $)$,

$\mathrm{C}_{17}(\mathrm{PP}=2 m$ TPPMS, LL=isoquinpk $)$,

$\mathrm{C}_{18}(\mathrm{PP}=2 p \mathrm{MPP}, \mathrm{LL}=$ bopy $), \mathrm{C}_{19}(\mathrm{PP}=2 p \mathrm{MPP}, \mathrm{LL}=2$-ap $)$,

$\mathrm{C}_{20}(\mathrm{PP}=2 p \mathrm{MPP}, \mathrm{LL}=2-\mathrm{apz}), \mathrm{C}_{21}(\mathrm{PP}=2 p \mathrm{MPP}, \mathrm{LL}=$ isoquinpk $)$,

$\mathrm{C}_{22}(\mathrm{PP}=$ dppe, $\mathrm{LL}=$ bopy $), \mathrm{C}_{23}(\mathrm{PP}=$ dppe, $\mathrm{LL}=2$-ap $)$,

$\mathrm{C}_{24}(\mathrm{PP}=$ dppe, $\mathrm{LL}=2$-apz $), \mathrm{C}_{25}(\mathrm{PP}=\mathrm{dppe}, \mathrm{LL}=$ isoquinpk $)$,

Fig. 2. Copper(I) complexes of diphosphane and bidentate N, O-heteroaromatic ligand (Machado et al., 2020)

The order of cytotoxicity of the complexes toward the LNCap cell was found to be 
$\mathrm{C}_{23}>\mathrm{C}_{10}>\mathrm{C}_{25}>\mathrm{C}_{11}>\mathrm{C}_{12}>\mathrm{C}_{17}>\mathrm{C}_{13}>\mathrm{C}_{19}>\mathrm{C}_{21}>\mathrm{C}_{18}$ thereby indicating the larger extent of contribution by 1,2 (bis(diphenylphosphano) ethane), diphenylphosphane, and 2-acetyl pyridine than that by other phosphane and heterocyclic ring in the cytotoxicity. The most active complex $\mathrm{C}_{23}$ (70 fold higher activity toward LNCap than normal prostate cell RWPE) exhibited a high level of cellular internalization, intracellular reactive oxygen species (ROS) generation, and cell death activation mechanism via apoptosis/necrosis (Machado et al., 2020).

\section{Phosphane and pyrazolyl copper(I) complexes}

The in vitro cytotoxic study of copper(I) complexes of $\mathrm{N}$ methyl-d-aspartated bis(pyrazol-1-yl) acetate and phosphane ligands $\left(\mathrm{C}_{26}-\mathrm{C}_{33}\right)$ (Fig. 3) against human pancreatic cancer; PSN-1, BxPC3, breast cancer; MCF-7, oral squamous; H157, skin cancer; A431, A431-Pt, ovarian cancer; A2780, A2780cis, A2780ADR reported higher anticancer potency $\left(\mathrm{IC}_{50} 0.01-5.9 \mu \mathrm{M}\right)$ than that of their corresponding ligands and standard drug cisplatin $\left(\mathrm{IC}_{50} 0.45-26.7 \mu \mathrm{M}\right)$.

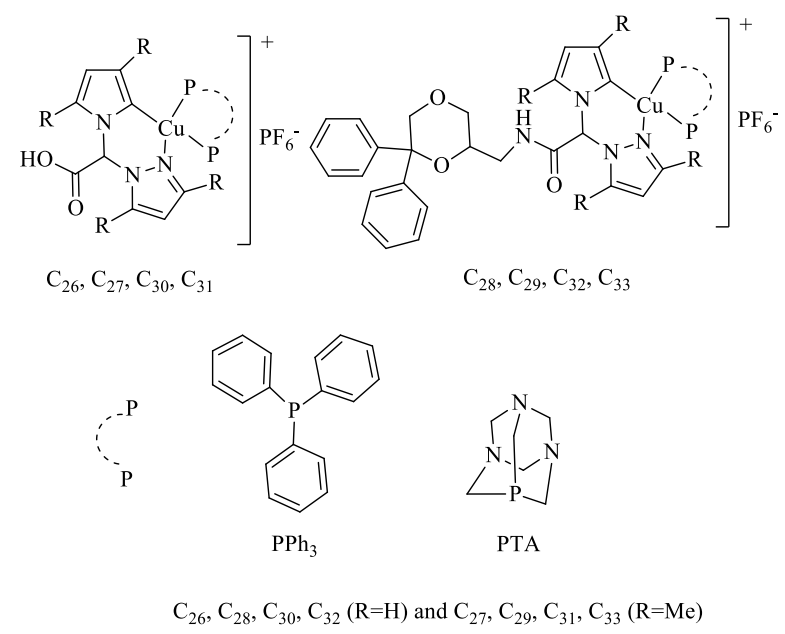

Fig. 3. Copper(I) complexes of phosphane (triphenylphosphine, $\quad \mathrm{PPh}_{3}$ or 1,3,5-triaza-7phosphaadamantane, PTA) and bis(pyrazol-1-yl) acetate ligands functionalized with an N-methyl-daspartate (NMDA) receptor antagonist (Pellei et al., 2020)

All the complexes exhibited very high cytotoxicity even in three dimensional (3D) cell culture of $\mathrm{H} 157$ ( $\mathrm{IC}_{50}$ 2.7$13.0 \mu \mathrm{M})$ and BxPC3 ( $\left.\mathrm{IC}_{50} 1.2-10.2 \mu \mathrm{M}\right)$ cancer cells compared with cisplatin against $\mathrm{H} 157\left(\mathrm{IC}_{50} 52.51 \mu \mathrm{M}\right)$ and BxPC3 ( IC $\left._{50} 100.5 \mu \mathrm{M}\right)$. The highest inhibitory effect by the complexes $\mathrm{C}_{29}\left(\mathrm{IC}_{50} 2.7 \mu \mathrm{M}\right)$ and $\mathrm{C}_{33}\left(\mathrm{IC}_{50} 1.2 \mu \mathrm{M}\right)$ in $3 \mathrm{D}$ spheroid indicated that triphenyl phosphane and PTA have a large contribution to anticancer potency. The ability of the complexes to cross the cellular plasmalemma resulted in the accumulation of copper in cancer cells showed a significant anticancer effect and overcome the cisplatin and multidrug resistance because they were able to slightly induce the DNA cleavage due to the limited generation of ROS (Pellei et al., 2020).

\section{Bis(diphenylphosphino)ferrocene and bidentate heteroaromatic copper(I) complexes}

The in vitro cytotoxic study of copper(I) complexes of 1,1-bis(diphenylphosphino)ferrocene and N,N-, N,O- and N, S-heteroaromatic bidentate ligands, $\left(\mathrm{C}_{34}-\mathrm{C}_{41}\right)$ (Fig. 4) against human breast cancer cells; MCF7, MDA-MB231 exhibited very high anticancer activity with far lower $\mathrm{IC}_{50}$ values (6 to 76 folds against MCF) compared with standard drug cisplatin. All the complexes performed good action toward both cancer cells but slightly better action toward MCF-7 cell. As compared to the precursor, the presence of ferrocene moiety in the phosphane copper(I) complexes did not show any improvement in cytotoxicity indicating that only phosphane ligands have a significant contribution to enhance the anticancer activity during coordination with copper(I) ion (Bravo et al., 2019).
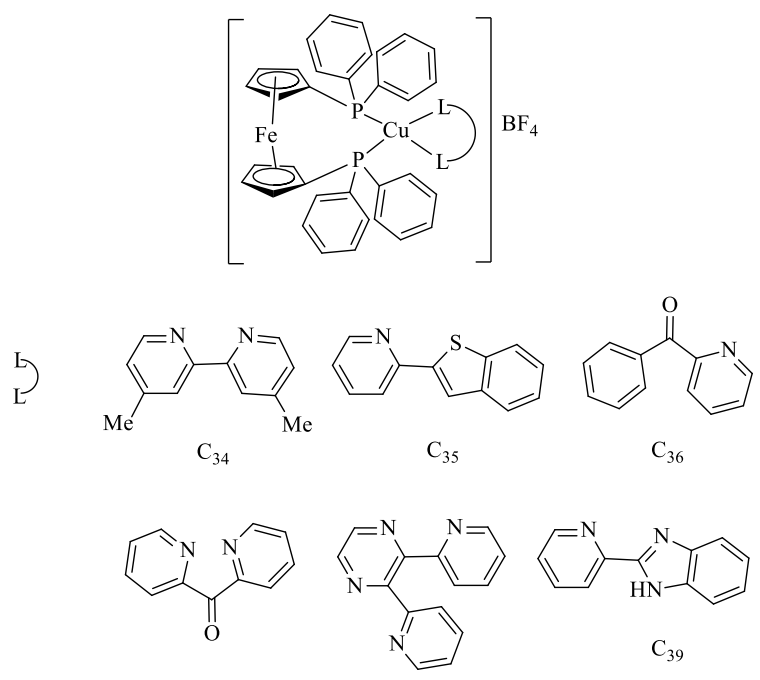

$\mathrm{C}_{37} \quad \mathrm{C}_{38}$

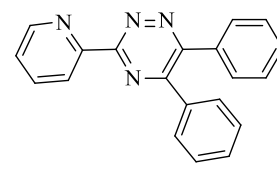

$\mathrm{C}_{40}$

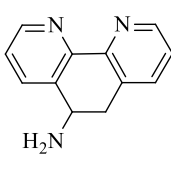

$\mathrm{C}_{41}$
Fig. 4. Copper(I) complexes of 1,1-Bis(diphenylphosphino)ferrocene and N,N-, N,O- and N,Sheteroaromatic bidentate ligands (Bravo et al., 2019)

Bis(acetophenone thosemicarbazone) copper(I) complexes

The in vitro and in vivo studies of copper(I) complexes of bis(acetophenone thosemicarbazone)/bis(p-substituted acetophenone thiosemicarbazone) $\left(\mathrm{C}_{42}-\mathrm{C}_{47}\right)$ (Fig. 5) against cancer cell lines- MCF-7 (human breast adenocarcinoma), HeLa (cervical), Hep-2 (epithelioma), 
Ehrlich ascites carcinoma (EAC) and normal cell lines; NHDF (normal human dermal fibroblasts) and L6 myotubes showed their anticancer activity at the micro molar concentration ( $\left.\mathrm{IC}_{50} 10.9-18.9 \mu \mathrm{M}, \mathrm{MCF}-7\right)$ as comparable to cisplatin ( $\mathrm{IC}_{50} 12.1 \mu \mathrm{M}, \mathrm{MCF}-7$ ) by DNA (pBR322) cleavage through a hydrolytic pathway and caspase-dependent- mitochondrial-mediated cell apoptosis via ROS production (Mahendiran et al., 2018a). These complexes were able to reduce the volume of tumors in female Swiss albino mice by inducing cell apoptosis and $\mathrm{S}$ phase (DNA synthesis) arrest with the mitochondrial controlled pathway. The complexes strongly killed the EAC tumor cell line with no toxicity against normal cells (Mahendiran et al., 2018a).

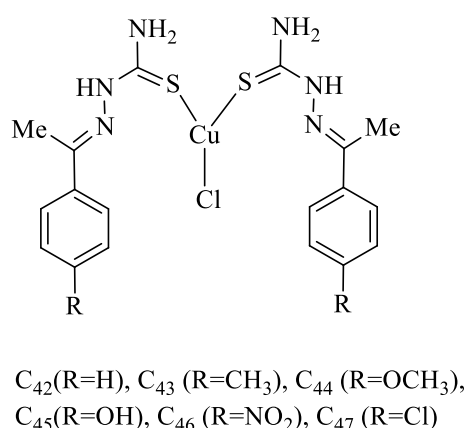

Fig. 5. Copper(I) bis(acetophenone thosemicarbazone) /bis(p-substituted acetophenone thiosemicarbazone) (Mahendiran et al., 2018a)

Copper(I) complexes of dihydropyrimidine derivative with phenyl moiety

The in vitro cytotoxic study of copper(I) complexes of methyl 4-aryl-6-methyl-3,4-dihydropyrimidine-2 $(1 \mathrm{H})$ thione-5-carboxylate $\left(\mathrm{C}_{48}-\mathrm{C}_{50}\right)$ (Fig. 6) [aryl = 4-(tertbutyl)phenyl $\left(\mathrm{C}_{48}\right)$, 2,6-dichloro phenyl $\left(\mathrm{C}_{49}\right)$, 2,4-dichloro phenyl $\left.\left(\mathrm{C}_{50}\right)\right]$ against human colorectal cancer $(\mathrm{CRC})$ cell line, Caco-2 exhibited higher antitumor activity ( $\mathrm{IC}_{50}$ 25.03-38.83 $\mu \mathrm{M})$ than that of the standard drug cisplatin ( $\mathrm{IC}_{50} 35.42 \mu \mathrm{M}$ ). The complexes $\mathrm{C}_{48}$ and $\mathrm{C}_{49}$ strongly induced the apoptosis of Caco- 2 cell model. The order of anticancer activity of the complexes was found to be $\mathrm{C}_{49}>$ $\mathrm{C}_{48}>\mathrm{C}_{50}$ (Gonzalez-Ballesteros et al., 2016).

\section{Copper(I) complexes of $\mathbf{N}$-aryl triaza phosphaadamantane and imidazolyl benzene derivative}

The study of in vitro cytotoxic activity of copper(I) complexes), $[\mathrm{Cu}(\mathrm{L})(\mathrm{PTA}-\mathrm{PhR})]\left(\mathrm{PF}_{6}\right)\left(\mathrm{C}_{51}-\mathrm{C}_{53}\right)$ (Fig. 7) having $\mathrm{NCN}$ pincer (L) and N-aryl-1,3,5-triaza-7phosphaadamantane (PTA-PhR) ligand [L = 5-methoxy1,3-bis (1-methyl-1H-benzo[d]imidazol-2-yl)benzene)] against A549 (human lung), A375 (melanoma), MCF-7 (breast), LoVo (colon adenocarcinoma), HeLa cervical cancer cell lines, and HEK293 (non-malignant fibroblasts) showed higher antitumor activity $\left(\mathrm{IC}_{50} \quad 0.98-21.57 \mu \mathrm{M}\right)$ than that of the standard drug cisplatin $\left(\mathrm{IC}_{50} 2.19-23.87\right.$ $\mu \mathrm{M})$ and their corresponding ligand $\left(\mathrm{IC}_{50}>100 \mu \mathrm{M}\right)$.

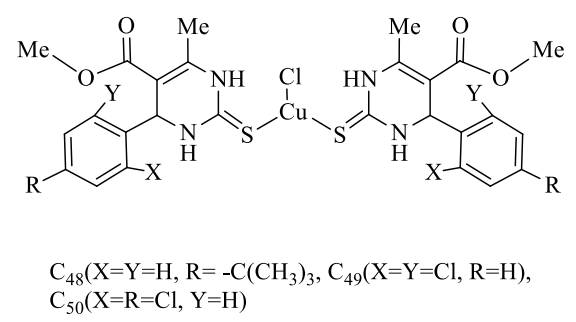

Fig. 6. Copper(I) complexes of methyl 4-aryl-6-methyl3,4-dihydropyrimidine-2(1H)thione-5-carboxylate (Gonzalez-Ballesteros et al., 2016)

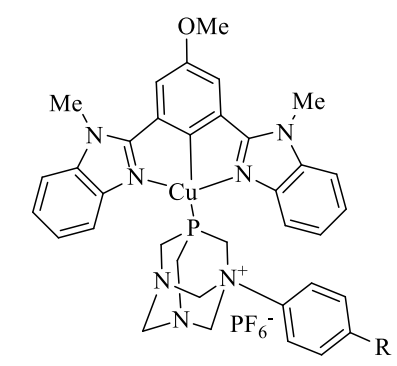

$\mathrm{C}_{51}\left(\mathrm{R}=\mathrm{CH}_{3}\right), \mathrm{C}_{52}\left(\mathrm{R}=\mathrm{CH}_{3} \mathrm{CH}_{2}-\right), \mathrm{C}_{53}\left(\mathrm{R}=\left(\mathrm{CH}_{3}\right)_{2} \mathrm{CH}-\right)$

Fig. 7. Copper(I) complexes of $\mathrm{N}$-aryl triaza phosphaadamantane and imidazolyl benzene derivative (Tabrizi \& Chiniforoshan, 2017)

All the complexes showed a lower value of malignant behavior $\left(\mathrm{IC}_{50} 75.52-92.13 \mu \mathrm{M}\right)$ than that of cisplatin $\left(\mathrm{IC}_{50} 19.32 \mu \mathrm{M}\right)$ when tested against HEK293. The experimental results showed that the complexes $\left(\mathrm{C}_{51}-\mathrm{C}_{53}\right)$ bind to circulating tumor deoxyribonucleic acid (CT DNA) through intercalation mode and hence the order of hypochromism magnitude and antitumor activity was found to be $\mathrm{C}_{53}\left(\mathrm{IC}_{50} 0.98-13.21 \mu \mathrm{M}\right)>\mathrm{C}_{52}\left(\mathrm{IC}_{50} 2.45\right.$ $18.32 \mu \mathrm{M}) \quad>\mathrm{C}_{51} \quad\left(\mathrm{IC}_{50}\right.$ 3.61-21.57 $\left.\mu \mathrm{M}\right) \quad($ Tabrizi \& Chiniforoshan, 2017).

\section{5-Nitroimidazole conjugated heteroscorpionate copper(I) complexes}

The study of in vitro cytotoxic activity of copper(I) complexes of 5-nitroimidazole conjugated heteroscorpionate ligands viz. 2,2-bis(pyrazol-1-yl)-N-(2(2-methyl-5-nitro-1H-imidazol-1-yl)ethyl)acetamide $\left(\mathrm{C}_{54}{ }^{-}\right.$ $\mathrm{C}_{55}$ ) (Fig. 8) against A431 (cervical), BxPC3 (pancreatic), HCT-15 (colon), MCF-7 (breast), A549 (lung), and 2008 (ovarian) cancer cell lines exhibited about 2.5 folds higher antitumor activity $\left(\mathrm{IC}_{50} 1.4-15.8 \mu \mathrm{M}\right)$ than that of the standard drug CDDP (cisplatin) and their corresponding ligands $\left(\mathrm{IC}_{50}>50 \mu \mathrm{M}\right)$ by constantly inducing a massive cytoplasmic vacuolization and induction of paraptotic-like cancer cell death. The complex $\mathrm{C}_{54}$ was found to have a higher antitumor activity (about 1.4-fold) than that of the compounds $\mathrm{C}_{55}$ and cisplatin. The cytotoxic results also 
exhibited a higher antitumor activity for copper(I) complexes (about 2 folds) than that of their corresponding copper(II) complexes (Pellei et al., 2018).

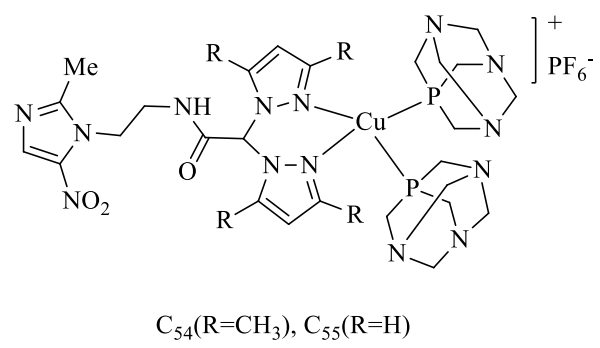

Fig. 8. Copper(I) complexes of 2,2-bis(pyrazol-1-yl)-N-(2(2-methyl-5-nitro-1H-imidazol-1-yl)ethyl)acetamide ligand (Pellei et al., 2018)

Fluoroquinolones viz. ciprofloxacin and norfloxacin copper(I) complexes

The in vitro cytotoxic study of copper(I) complexes of $2^{\text {nd }}$ and $3^{\text {rd }}$ generation antibiotics (fluoroquinolones) viz. ciprofloxacin $\left(\mathrm{C}_{56}\right)$ and norfloxacin $\left(\mathrm{C}_{57}\right)$ (Fig. 9) against CT26 (mouse colon carcinoma) and A549 (human lung adenocarcinoma) showed pronounced antitumor activity $\left(\mathrm{IC}_{50}\right.$ 2.9-5.0 $\mu \mathrm{M}, \quad \mathrm{A} 549$ and $\mathrm{IC}_{50} 2.4-5.2 \mu \mathrm{M}, \mathrm{CT} 26$ ) than that of their corresponding $\mathrm{Cu}(\mathrm{II})$ ones via $\mathrm{ROS}$ generation, DNA interactions and the sugar-phosphate backbone of its chain due to their redox reactivity. The complex $\mathrm{C}_{56}$ have higher antitumor activity than that of the complex $\mathrm{C}_{57}$ (Bykowska et al., 2018).

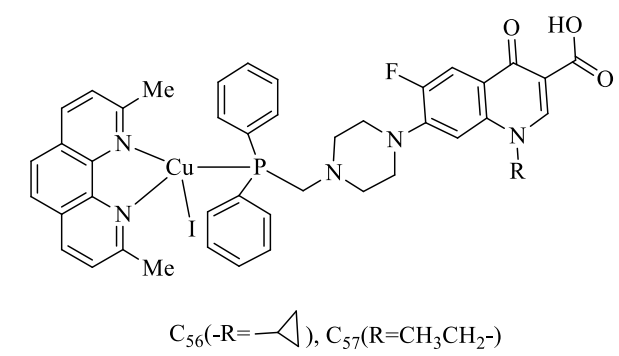

Fig. 9. Copper(I) complexes of fluoroquinolones viz. ciprofloxacin and norfloxacin (Bykowska et al., 2018)

\section{(-)-Camphor thiosemicarbazone copper(I) complex}

The in vitro cytotoxic study of (-)-camphor thiosemicarbazone copper(I) complex $\left(\mathrm{C}_{58}\right)$ (Fig. 10) against MCF-7 cell line showed that the $\mathrm{Cu}(\mathrm{I})$ complex experienced remarkable dose-dependent cytotoxic activity through apoptosis $\left(\mathrm{IC}_{50} 9.8 \mu \mathrm{M}\right)$ as that of the standard cisplatin and higher than that of uncomplexed ligand $\left(\mathrm{IC}_{50}\right.$ $>50 \mu \mathrm{M})$, mononuclear $\mathrm{Zn}(\mathrm{II})$ complexes $\left(\mathrm{IC}_{50} 14-20 \mu \mathrm{M}\right)$ and binuclear $\mathrm{Pd}(\mathrm{II})$ complexes ( $\mathrm{IC}_{50}$ 12.5-12.9 $\mu \mathrm{M}$ ). The complexation of ligand to metal ion significantly enhanced its anticancer activity and hence the order of anticancer activity was found to be- $\mathrm{Cu}(\mathrm{I})$ complex $>\mathrm{Pd}$ complex $>$ Zn-complex $>$ Ligand (Kokina et al., 2019).

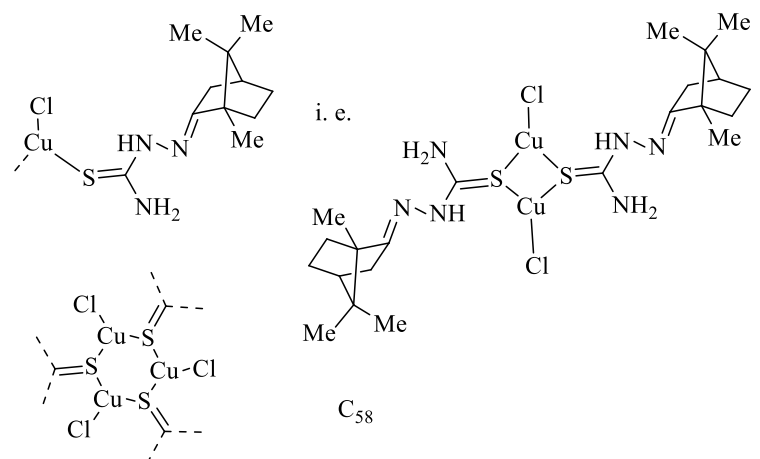

Fig. 10. Copper(I) complex of (-)-camphor thiosemicarbazone in different possible forms (Kokina et al., 2019)

\section{9-Quinolylanthrahydrazone copper(I) complex}

The in vitro cytotoxic study of copper(I) complex of 9quinolylanthrahydrazone $(9-\mathrm{AQH}),\left[\mathrm{Cu}^{\mathrm{I}}(9-\mathrm{AQH})_{2}\right] \mathrm{NO}_{3}$, $\left(\mathrm{C}_{59}\right)$ (Fig. 11) against MGC-803 (human gastric cancer) and other typical cancer cell lines exhibited remarkably higher broad-spectrum antiproliferation and cell apoptosis via mitochondrial pathway than that of their corresponding $\mathrm{Cu}(\mathrm{II}), \mathrm{Co}(\mathrm{II})$ and $\mathrm{Ni}(\mathrm{II})$ complexes (Liu et al., 2021).

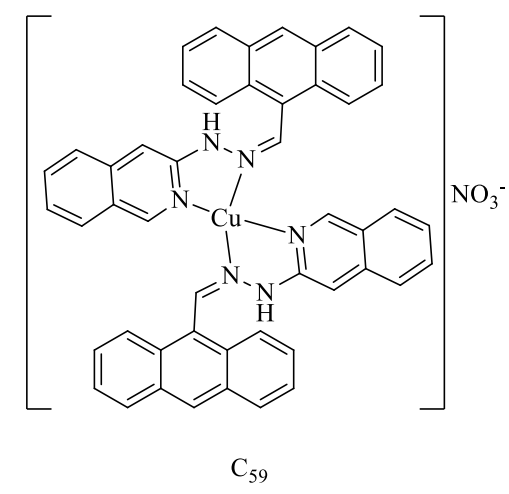

Fig. 11. Copper(I) complexes of quinolylanthrahydrazone (Liu et al., 2021)

Diphosphane and bidentate N, N-, N,O- and N, Sheteroaromatic copper(I) complexes

The in vitro cytotoxic activity of copper(I) complexes of triphenyl phosphane and N,N-, N,O-, and N,S- bidentate ligands $\left(\mathrm{C}_{60}-\mathrm{C}_{65}\right)$ (Fig. 12) $[\mathrm{L}=2$-(2-pyridyl)benzo[b] thiophene (pbt) $\left(\mathrm{C}_{60}\right), 2$ - benzoylpyridine (bopy) $\left(\mathrm{C}_{61}\right)$, di(2-pyridyl)ketone (dpk) $\quad\left(\mathrm{C}_{62}\right), \quad 2,3$-bis(2pyridyl)pyrazine (dpp) ( $\left.\mathrm{C}_{63}\right), 2,2$ '-bipyridine (2,2'-bipy) $\left(\mathrm{C}_{64}\right)$ and 2,2'-bipyridine-4,4'-dicarboxylic acid (dcbipy) $\left(\mathrm{C}_{65}\right)$ against MCF-7 (human breast cancer) cell line exhibited significant anticancer activity with the far lower $\mathrm{IC}_{50}$ values $(6.6-17.7 \mu \mathrm{M})$ than that of cisplatin $\left(\mathrm{IC}_{50} 59.0\right.$ $\mu \mathrm{M})$. The complexes $\mathrm{C}_{60}$ and $\mathrm{C}_{62}$ were found to induce the apoptosis of MCF-7 cell death and a cell cycle arrest in the $\mathrm{G} 2 / \mathrm{M}$ phase but complex $\mathrm{C}_{64}$ exhibited a significant 
cytostatic effect, resulting cell cycle arrest at the $S$ phase. The order of anticancer activity was found to be$\mathrm{C}_{60}>\mathrm{C}_{64}>\mathrm{C}_{62}>\mathrm{C}_{61}>\mathrm{C}_{65}>\mathrm{C}_{63}$ (Morais et al., 2018b).
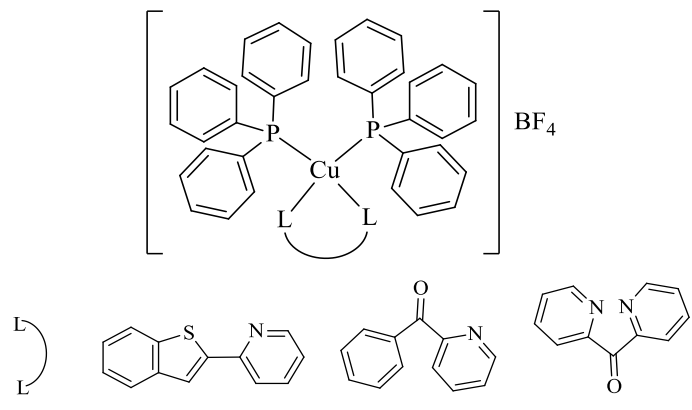

$\mathrm{C}_{60}$

$\mathrm{C}_{61}$

$\mathrm{C}_{62}$
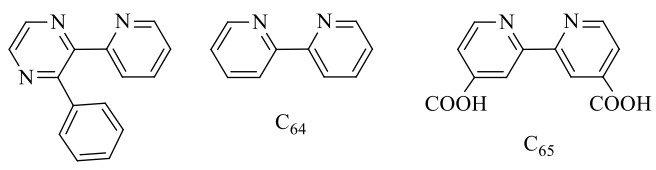

$\mathrm{C}_{63}$

Fig. 12. Copper(I) complexes of triphenyl phosphane and $\mathbf{N}, \mathbf{N}-, \mathbf{N}, \mathbf{O}$ - and $\mathbf{N}, \mathbf{S}$ - bidentate ligands (Morais et al., 2018)

\section{Copper(I) complexes of biquinoline/substituted} phenanthroline and sparfloxacin derivative

The in vitro cytotoxic study of copper(I) complexes of a $3^{\text {rd }}$ generation fluoroquinolone antibiotic agent (phosphine derivative of sparfloxacin) and 2,2'-biquinoline (bq) or 2,9-dimethyl-1,10-phenanthroline (dmp) $\left(\mathrm{C}_{66}-\mathrm{C}_{69}\right)$ (Fig. 13) against CT26 (mouse colon carcinoma) and A549 (human lung adenocarcinoma) exhibited higher anticancer activity $\left(\mathrm{IC}_{50} 7.51-33.79 \mu \mathrm{M}\right)$ than that of their corresponding ligands ( $\mathrm{IC}_{50}$ 104.08-264.28 $\left.\mu \mathrm{M}\right)$ via reactive oxygen species (ROS) generation, plasmid DNA damage and the induction of cell apoptosis. The order of anticancer activity was found to be- $\mathrm{C}_{67}>\mathrm{C}_{66}>\mathrm{C}_{68}>\mathrm{C}_{69}$ (Komarnicka et al., 2016b).

\section{Copper(I) complexes of biquinoline/substituted phenanthroline and lomefloxacin derivative}

The in vitro cytotoxic study of copper(I) complexes of a $2^{\text {nd }}$ generation fluoroquinolone antibiotic agent (phosphine derivative of lomefloxacin) and 2,2'-biquinoline (bq) or 2,9-dimethyl-1,10-phenanthroline (dmp) $\left(\mathrm{C}_{70}-\mathrm{C}_{73}\right)$ (Fig. 14) against CT26 (mouse colon carcinoma), A549 (human lung adenocarcinoma) and $\mathrm{MCF}-7$ (breast cancer) exhibited higher anticancer activity $\left(\mathrm{IC}_{50}\right.$ 5.8-38.0 $\left.\mu \mathrm{M}\right)$ than that of their corresponding ligands $\left(\mathrm{IC}_{50} 176.0-326.0\right.$ $\mu \mathrm{M})$ and cisplatin $\left(\mathrm{IC}_{50} 51.0-242.0 \mu \mathrm{M}\right)$ via singlestranded cleavage of the sugar-phosphate backbone of plasmid DNA but the complexes $\mathrm{C}_{72}$ and $\mathrm{C}_{73}$ also intercalate in DNA. The complexes showed the interaction with human serum albumin (HAS) without any change in its secondary structure. The cleavage in singleand/or double-strain plasmid was observed after the addition of $\mathrm{H}_{2} \mathrm{O}_{2}$. The order of anticancer activity was found to be- $\mathrm{C}_{70}>\mathrm{C}_{71}>\mathrm{C}_{72}>\mathrm{C}_{73}$ in CT26 and A549 cells but $\mathrm{C}_{71}>\mathrm{C}_{70}>\mathrm{C}_{73}>\mathrm{C}_{72}$ in MCF-7 cells (Komarnicka et al., 2016a).

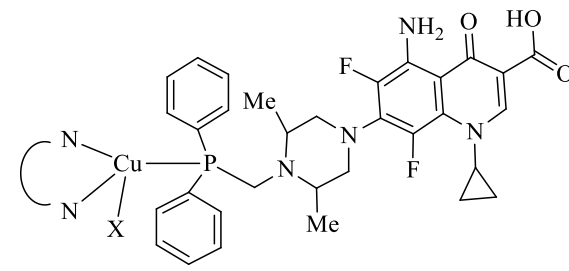<smiles></smiles>

$\mathrm{C}_{66}(\mathrm{X}=\mathrm{I}, \mathrm{NN}=\mathrm{dmp}), \mathrm{C}_{67}(\mathrm{X}=\mathrm{NCS}, \mathrm{NN}=\mathrm{dmp})$, $\mathrm{C}_{68}(\mathrm{X}=\mathrm{I}, \mathrm{NN}=\mathrm{bq}), \mathrm{C}_{69}(\mathrm{X}=\mathrm{NCS}, \mathrm{NN}=\mathrm{bq})$

Fig. 13. Copper(I) complexes of phosphine derivative of sparfloxacin and 2,2'-biquinoline or 2,9-dimethyl1,10-phenanthroline (Komarnicka et al., 2016b)<smiles>[X]Cn1cc(C(=O)O)c(=O)c2cc(F)c(N3CCN(CP(c4ccccc4)c4ccccc4)C(C)C3)c(F)c21</smiles><smiles>Cc1ccc2ccc3ccc(C)nc3c2n1</smiles><smiles>c1ccc2nc(-c3cnc4ccccc4n3)ccc2c1</smiles>

$\mathrm{C}_{70}(\mathrm{X}=\mathrm{I}, \mathrm{NN}=\mathrm{dmp}), \mathrm{C}_{71}(\mathrm{X}=\mathrm{NCS}, \mathrm{NN}=\mathrm{dmp})$, $\mathrm{C}_{72}(\mathrm{X}=\mathrm{I}, \mathrm{NN}=\mathrm{bq}), \mathrm{C}_{73}(\mathrm{X}=\mathrm{NCS}, \mathrm{NN}=\mathrm{bq})$

Fig. 14. Copper(I) complexes of phosphine derivative of lomefloxacin and 2,2'-biquinoline or 2,9-dimethyl1,10-phenanthroline (Komarnicka et al., 2016a)

Phosphane and bidentate $\mathrm{N}, \mathrm{N}$ - or monodentate $\mathrm{N}$ heteroaromatic copper(I) complexes

The study of in vitro cytotoxicity of copper(I) complexes of triphenylphosphine $\left(\mathrm{PPh}_{3}\right)$ and phenanthroline (phen) $\left(\mathrm{C}_{74}\right)$ neocuproine (neo) $\left(\mathrm{C}_{75}\right)$ or dimethylbipyridine (dmbpy) $\left(\mathrm{C}_{76}\right)$ (Fig. 15) toward MDA MB 231 (human metastatic breast adenocarcinoma), A459 (human lung epithelial carcinoma) and HeLa (human cervical adenocarcinoma) cell lines exhibited much higher anticancer activity $\left(\mathrm{IC}_{50} 1.3-8.4 \mu \mathrm{M}\right)$ than that of the standard drug cisplatin $\left(\mathrm{IC}_{50} 30-50 \mu \mathrm{M}\right)$. The molecule having a higher extent of lipophilicity was observed as a 
strong anti-cancer agent. The anticancer activity was observed in the order of; $\mathrm{C}_{75}>\mathrm{C}_{74}>\mathrm{C}_{76}$ (Alvarez et al., 2017).
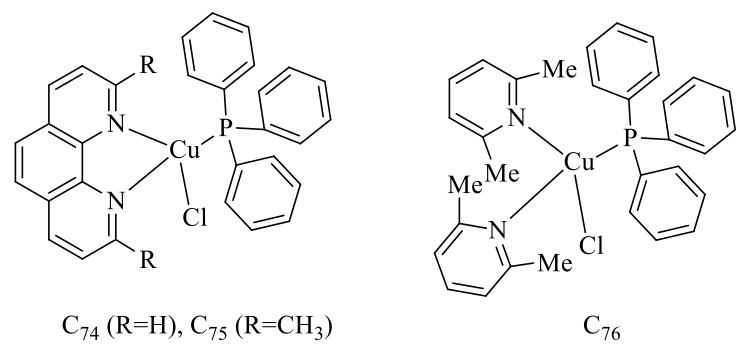

Fig. 15. Copper(I) complexes of triphenylphosphine and phenanthroline, neocuproine, or dimethylbipyridine (Alvarez et al., 2017)

Copper(I) complex of substituted phenanthroline and sarcosine-glycine derivative

The in vitro cytotoxic study of copper(I) complex of phosphine-peptide conjugate $\left(\mathrm{PPh}_{2} \mathrm{CH}_{2} \mathrm{Sar}-\mathrm{Gly}-\mathrm{OH}\right)$ derived from sarcosine-glycine (SarGly) and 2,9dimethyl-1,10-phenanthroline (dmp), $\left[\mathrm{CuI}(\mathrm{dmp})\left(\mathrm{P}(\mathrm{Ph})_{2} \mathrm{CH}_{2}\right.\right.$-Sar-Gly-OH $\left.)\right] \quad\left(\mathrm{C}_{77}\right) \quad($ Fig. 16) toward CT26 (mouse colon carcinoma), A549(human lung adenocarcinoma) and MCF-7 (human breast adenocarcinoma) exhibited higher anticancer activity $\left(\mathrm{IC}_{50} 0.98-3.12 \mu \mathrm{M}\right)$ than that of its corresponding ligand $\left(\mathrm{IC}_{50}>100 \mu \mathrm{M}\right)$ and standard drug cisplatin $\left(\mathrm{IC}_{50} 50.9\right.$ to $>$ $100 \mu \mathrm{M})$ via a high level of ROS generation that resulted to oxidative damages of the sugar-phosphate backbone of plasmid DNA and via apoptotic cell deaths in MCF-7 cells with the simultaneous decrease of mitochondrial membrane potential and increase of caspase- 9 and -3 activities.

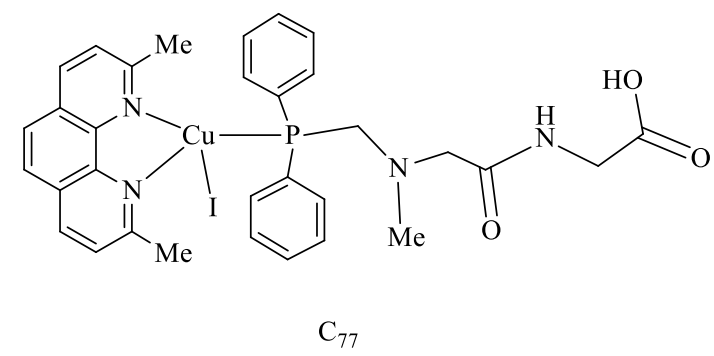

Fig. 16. Copper(I) complex of phosphine-peptide conjugate derived from sarcosine-glycine and 2,9dimethyl-1,10-phenanthroline (Komarnicka et al., 2018)

The $\mathrm{IC}_{50}$ value of the complex against normal cell line MRC5 (primary line of human pulmonary fibroblasts) was found to be $78.56 \mu \mathrm{M}$ and that of cisplatin was $31.48 \mu \mathrm{M}$. The accumulation of the complex $\mathrm{C}_{77}$ in cells increased with increasing time such as $96 \%$ inside MCF-7 and only $20 \%$ in MRC5 cell indicating that the complex $\mathrm{C}_{77}$ experienced higher anticancer potency and less toxicity in comparison to the standard drug (Komarnicka et al., 2018).

\section{Copper(I) complexes of phenyl- N'(methoxycarbonyl)thiocarbamides derivative}

The in vitro cytotoxic study of copper(I) complexes of $\mathrm{N}$ (2-chloro-4-nitro/2/4 methoxy)phenyl$\mathrm{N}$ '(methoxycarbonyl)thiocarbamides $\left(\mathrm{C}_{78}-\mathrm{C}_{81}\right)$ (Fig. 17) toward human ovarian cancer; IGROV-1, A2780/CP, A2780), cervical cancer; 2008, C13* and human normal hepatic cell; WRL-68 showed that the coordination of ligands to the metal ion substantially increased ( $2-3$ folds) the growth inhibition toward cancer cell but decreased the effect toward normal cell through the DNA damage. Thus the complexes were found to be less toxic toward normal cells (Pandey et al., 2019a). The redox behavior of $\mathrm{Cu}(\mathrm{I})$ ion in the complexes caused to produce a large quantity of highly reactive $\cdot \mathrm{OH}$ (hydroxyl) radical that is responsible for the damages of DNA, lipid, or protein thereby showing a higher anticancer potency of complexes than their respective ligands (Mosmann, 1983, Lopes et al., 1997, Lee \& Steinert, 2003, Stepanenko \& Dmitrenko, 2015, Pandey et al., 2019ba).

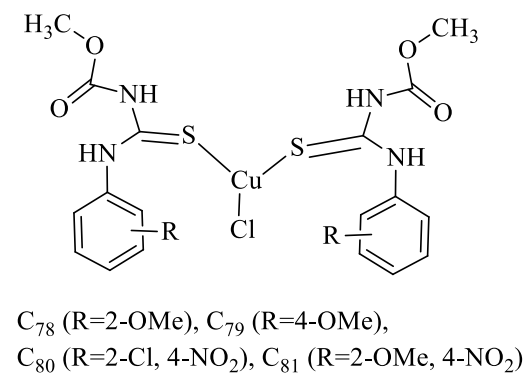

Fig. 17. Copper(I) complex of $\mathrm{N}$-(2-chloro-4-nitro/2/4 methoxy)phenyl-N' thiocarbamides (Pandey et al., 2019) (methoxycarbonyl)

\section{$\mathbf{N}, \mathbf{N}^{\prime}$-disubstituted isobutoxycarbonyl thiocarbamide copper(I) complexes}

The results of in vitro cytotoxic assay of copper(I) complexes of $\mathrm{N}, \mathrm{N}^{\prime}$-disubstituted isobutoxycarbonyl thiocarbamide $\left(\mathrm{C}_{82}-\mathrm{C}_{85}\right)$ (Fig. 18) against cancer cells; IGROV-1, A2780, A2780/CP, C13* (cervical), 2008 (cervical) and normal hepatic cell; WRL-68 showed that all the complexes with redox behavior have better anticancer potency (9-10 folds) than their corresponding ligands may be due to having a significant DNA cleavage activity. The complexes performed well on cervical cancer, $\mathrm{C} 13^{*}$ compared to cisplatin. All the complexes induced cell apoptosis by blocking the progression of cell cycles of 2008 (cervical cancer), C13*(cervical cancer), and IGROV-1 cancer cells in $\mathrm{G}_{0} / \mathrm{G}_{1}$ phase. The presence of a highly electronegative atom or group of atoms near the metallic center helped to exhibit good anticancer potency by complexes (Pandey et al., 2019b). 
<smiles>[R]NC(NC(=O)OCC(C)C)=S=C(Cl)Cl</smiles>

$\mathrm{C}_{82}\left(\mathrm{R}=2,4-\mathrm{di}-\mathrm{ClC}_{6} \mathrm{H}_{3}\right), \mathrm{C}_{83}\left(\mathrm{R}=2-\mathrm{Cl}-4-\mathrm{NO}_{2} \mathrm{C}_{6} \mathrm{H}_{3}\right)$, $\mathrm{C}_{84}\left(\mathrm{R}=2-\mathrm{OCH}_{3} \mathrm{C}_{6} \mathrm{H}_{4}\right), \mathrm{C}_{85}\left(\mathrm{R}=4-\mathrm{Cl}-2-\mathrm{NO}_{2} \mathrm{C}_{6} \mathrm{H}_{3}\right)$

Fig. 18. Copper(I) complexes of $\mathbf{N}, \mathbf{N}^{\prime}$-disubstituted isobutoxycarbonyl thiocarbamide (Pandey et al., 2019b)

Copper(I) complex of Phosphane and pyridine carboxaldehyde derivative

The study of in vitro cytotoxicity of copper(I) complex of 5-dimethyl-2-phenyl-4-[(pyridin-2- ylmethylene)-amino]1,2-dihydropyrazol-3-one $\left(\mathrm{C}_{86}\right)$ (Fig. 19) against Hep2 (laryngeal epithelial), HeLa (cervical) and MCF-7 (breast) cancer cell lines assessed tremendous cell inhibitory activity $\left(\mathrm{IC}_{50} 3.04-19.25 \mu \mathrm{M}\right)$ compared to its ligand $\left(\mathrm{IC}_{50}\right.$ $>100 \mu \mathrm{M})$ and cisplatin ( $\mathrm{IC}_{50}$ 12.52-13.84 $\mu \mathrm{M}$ ) via plasmid DNA (pBR322) cleavage by hydrolytic pathway where binding with CT-DNA occurs through intercalative mode (Sathiyaraj et al., 2013).<smiles>Cc1c(N(/C=C2\CC=CC=N2)C(Cl)c2ccccc2)c(=O)n(-c2ccccc2)n1C</smiles>

Fig. 19. Copper(I) complex of 5-dimethyl-2-phenyl-4[(pyridin-2ylmethylene)-amino]-1,2dihydropyrazol-3-one (Sathiyaraj et al., 2013)

\section{Copper(I) complexes of phosphane and triazolyl derivative}

The in vitro cytotoxic study of copper(I) complexes of phosphane and dihydridobis(3-nitro1,2,4-triazolyl)borate $\left(\mathrm{C}_{87}-\mathrm{C}_{89}\right) \quad$ (Fig. 20) against HL60 (promyelocytic leukemia), A549 (lung cancer), A375 (melanoma), A431 (cervix carcinoma) and 2008 (ovarian cancer) reported higher cell inhibitory activity (especially in case of A549) than that of their corresponding ligands and cisplatin. In the case of $\mathrm{A} 549$ the $\mathrm{IC}_{50}$ of the complexes $\left(\mathrm{IC}_{50} 1.52-6.88\right.$ $\mu \mathrm{M})$ has been reported appreciably higher than that of their ligands $\left(\mathrm{IC}_{50} 68.12-71.6 \mu \mathrm{M}\right)$ and standard drug cisplatin $\left(\begin{array}{lll}\mathrm{IC}_{50} & 39.27 \mu & \mu \mathrm{M}\end{array}\right)$ through oxidative phosphorylation uncoupling by mitochondrial membrane potential dissipation (Marzano et al., 2006).

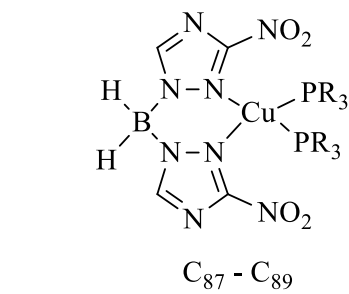

$\mathrm{C}_{87}\left(\mathrm{PR}_{3}=\mathrm{P}(\mathrm{m} \text {-tolyl })_{3}, \mathrm{C}_{88}\left(\mathrm{PR}_{3}=\mathrm{P}\left(\mathrm{C}_{6} \mathrm{H}_{5}\right)_{2}\right.\right.$

$\left(\mathrm{p}-\mathrm{C}_{6} \mathrm{H}_{4} \mathrm{COOH}\right), \mathrm{C}_{89}\left(\mathrm{P}\left(\mathrm{p}-\mathrm{C}_{6} \mathrm{H}_{4} \mathrm{~F}\right)_{3}\right.$

Fig. 20. Copper(I) complexes of phosphane and dihydridobis(3-nitro1,2,4-triazolyl)borate (Marzano et al., 2006)

Copper(I) complexes of dihydropyrimidine derivative with phenyl or naphthalenyl moiety

The in vitro cytotoxic study of copper(I) complexes of methyl 4-aryl (phenyl, 1-napthalenyl, 2-bromophenyl or 2-chlorophenyl) -6-methyl-3,4-dihydropyrimidine2(1H)thione-5-carboxylate $\left(\mathrm{C}_{90}-\mathrm{C}_{93}\right)$ (Fig. 21) against breast cancers; HCC1806 and MCF-7 showed that the complexes have highly aggressive anticancer potency toward HCC1806 ( IC $\left._{50} 5.30-7.96 \mu \mathrm{M}\right)$ compared to their corresponding ligands ( $\left.\mathrm{IC}_{50} 25.07->100 \mu \mathrm{M}\right)$ with the order of $\mathrm{C}_{92}>\mathrm{C}_{90}>\mathrm{C}_{91}>\mathrm{C}_{93}$ and MCF-7 $\left(\mathrm{IC}_{50}\right.$ 19.62-25.96 $\mu \mathrm{M}$; complexes, $\mathrm{IC}_{50} 80.72->100 \mu \mathrm{M}$; ligands) with the order of; $\mathrm{C}_{90}>\mathrm{C}_{92}>\mathrm{C}_{91}>\mathrm{C}_{93}$ may be due to different activities of the same substituent on different cell lines. These complexes also exhibited a higher cell inhibitory property than the standard drugs; doxorubicin and docetaxel (Gonzalez-Ballesteros et al., 2015).

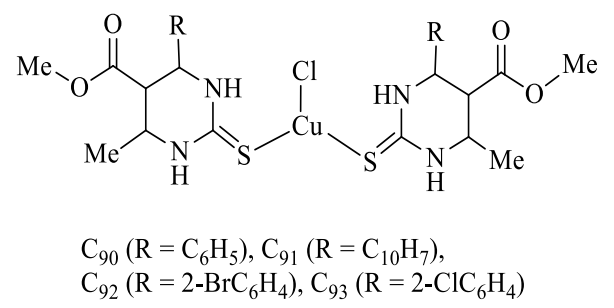

Fig. 21. Copper(I) complexes of methyl 4-aryl (phenyl, 1napthalenyl, 2-bromophenyl or 2-chlorophenyl) -6methyl-3,4-dihydropyrimidine-2(1H)thione-5carboxylate (Gonzalez-Ballesteros et al., 2015)

\section{5-Carbethoxy-2-thiouracil copper(I) complexes}

The in vitro cytotoxic study of copper(I) complexes of 5carbethoxy-2-thiouracil with or without diphosphane $\left(\mathrm{C}_{94}-\mathrm{C}_{99}\right) \quad$ (Fig. 22) against cancer cells; A549 (pulmonary), HeLa (epithelial), and non-cancer cell; MRC5 (fetal lung fibroblast) reported that the copper(I) complexes with highly toxic triphenylphosphine counterparts $\left(\mathrm{C}_{97}-\mathrm{C}_{99}\right)$ have substantial anticancer potency $\left(\mathrm{IC}_{50} 2.55-5.55 \mu \mathrm{M}\right)$ may be due to the stability of complexes by phosphane group. The complexes $\left(\mathrm{C}_{94}-\mathrm{C}_{96}\right)$ also reported a higher action of growth inhibition $\left(\mathrm{IC}_{50}\right.$ 
41.3-110 $\mu \mathrm{M})$ than that of free phosphane ligand $\left(\mathrm{IC}_{50}\right.$ $105-118 \mu \mathrm{M})$. The anticancer potency of these drugs may be performed by DNA cleavage and excess ROS production (Papazoglou et al., 2014).

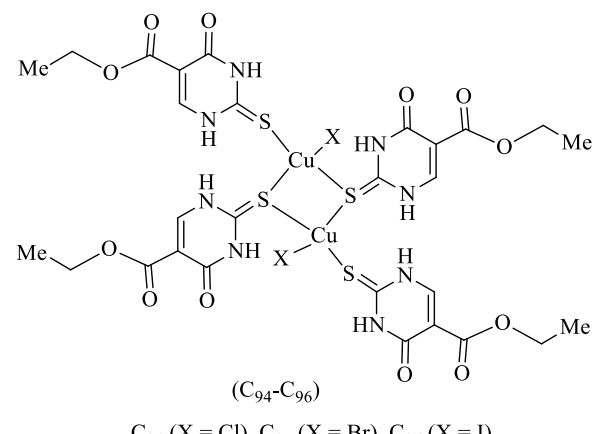

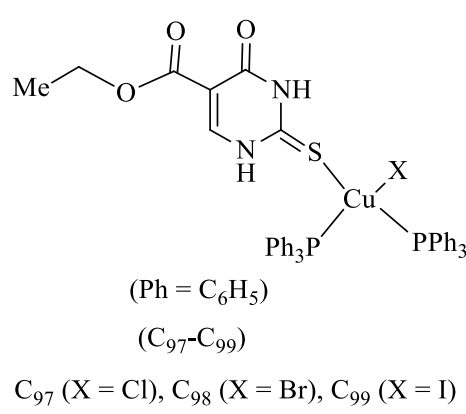

Fig. 22. Copper(I) complexes of 5-carbethoxy-2-thiouracil with or without diphosphane (Papazoglou et al., 2014)

\section{N-methyl triaza phosphaadamantane copper(I) complexes}

The in vitro cytotoxic test of copper(I) complexes of $\mathrm{N}$ methyl-1,3,5-triaza-7-phosphaadamantane (mPTA) phosphine $\left(\mathrm{C}_{100}-\mathrm{C}_{104}\right)$ (Fig. 23) against MCF-7 (breast), HeLa (cervix), A549 (pulmonary), HCT-15 (colon) and A375 (melanoma) cancers showed significant anticancer potency $\left(\mathrm{IC}_{50} 7.58-29.3 \mu \mathrm{M}\right)$ comparable to cisplatin. These complexes also showed remarkably lower resistance than cisplatin when tested against ovarian cancer 2008/C13* or 2008/C13*-Pt (resistance factor; $<7$ fold) and A431/A431-Pt cancer (resistance factor; $<2.5$ fold) indicating the different mechanism of action from the cisplatin (Porchia et al., 2009).

\section{Copper(I) complexes of $N$, N'-disubstituted thioamides}

The in vitro cytotoxic results of copper(I) complexes of $\mathrm{N}$-aryl, N'-isobutoxy/methoxycarbonyl thiocarbamide $\left(\mathrm{C}_{106}-\mathrm{C}_{108}\right)$ (Fig. 24) against A2780, A2780/CP, IGROV1, 2008 (cervical), and C13* (cervical) cancer cell lines showed the higher anticancer potency than that of their coordinating ligands through the mechanism of DNA damage (Singh et al., 2015, Pandey et al., 2018). The copper complexes tend to break the strand of induced DNA via highly reactive hydroxyl radical $(\cdot \mathrm{OH})$ and superoxide anion $\left(\mathrm{O}_{2}^{-}\right)$(Mosmann, 1983, Lopes et al., 1997, Lee \& Steinert, 2003, Stepanenko \& Dmitrenko, 2015). The presence of highly electronegative atoms or group of atoms on organic moiety has been found to cleave DNA more effectively (Shao et al., 2014, Stepanenko \& Dmitrenko, 2015) so the complexes $\mathrm{C}_{105}$ and $\mathrm{C}_{106}$ showed significant anticancer effect toward IGROV-1, 2008 (cervical) and C13* (cervical) cell lines.
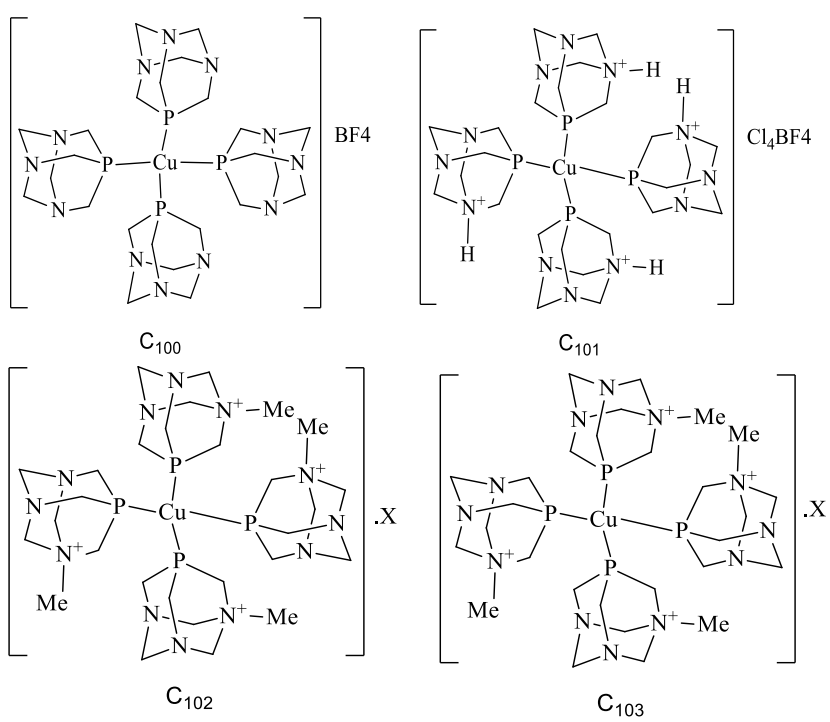

$\mathrm{C}_{102} ; \mathrm{X}=\left[\left(\mathrm{CF}_{3} \mathrm{SO}_{3}\right)_{4}\left(\mathrm{BF}_{4}\right)\right]$

$\mathrm{C}_{103} ; \mathrm{X}=\left[\left(\mathrm{CF}_{3} \mathrm{SO}_{3}\right)_{4}\left(\mathrm{PF}_{6}\right)\right]$

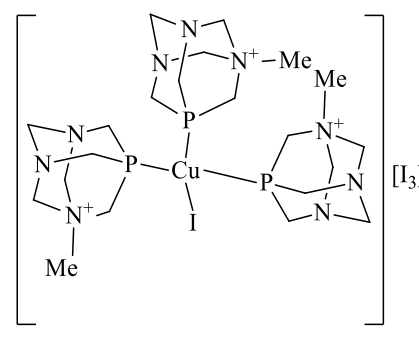

$\mathrm{C}_{104}$

Fig. 23. Copper(I) complexes of $\mathbf{N}$, N'-disubstituted thioamides (Porchia et al., 2014)<smiles>[R]NC(=S)NC(=O)OCC([Y4])C</smiles>

$\mathrm{C}_{105}-\mathrm{C}_{106}$<smiles>[R]OC(=O)NC(=NC(NC(=O)O[R])=[SH]CCl)Nc1cccc2ccccc12</smiles>

$\mathrm{C}_{107}-\mathrm{C}_{108}$
$\mathrm{C}_{105}\left(\mathrm{R}=4-\mathrm{OCH}_{3} \mathrm{C}_{6} \mathrm{H}_{4}\right), \mathrm{C}_{106}\left(\mathrm{R}=2-\mathrm{OCH}_{3}-4-\mathrm{NO}_{2} \mathrm{C}_{6} \mathrm{H}_{3}\right)$ $\mathrm{C}_{107}\left(\mathrm{R}^{\prime}=-\mathrm{CH}_{2} \mathrm{CH}\left(\mathrm{CH}_{3}\right)_{2}, \mathrm{C}_{108}\left(\mathrm{R}^{\prime}=-\mathrm{CH}_{3}\right)\right.$

Fig. 24. Copper(I) complexes of N-aryl, N'isobutoxy/methoxycarbonyl thiocarbamide (Singh et al., 2015, Pandey et al., 2018) 


\section{A unique copper(I/II) complex of hydroxyl naphthalene derivative}

In vitro cytotoxic study of a unique complex, 3-hydroxy naphthalene-2-carboxylic acid thiophene-2-ylmethylene hydrazide copper(I/II) $\left(\mathrm{C}_{109}\right)$ (Fig. 25) against A549 (lung) and MCF-7(breast) cancer cell lines exhibited almost double antiproliferation activity $\left(\mathrm{IC}_{50} 12-15 \mu \mathrm{M} / \mathrm{ml}\right)$ than its ligand $\left(\mathrm{IC}_{50} 25-32 \mu \mathrm{M} / \mathrm{ml}\right)$ and slightly higher than the standard cisplatin $\left(\mathrm{IC}_{50} 15-17 \mu \mathrm{M} / \mathrm{ml}\right)$ via $\mathrm{DNA}$ binding with intercalative mode (Anu et al., 2019).

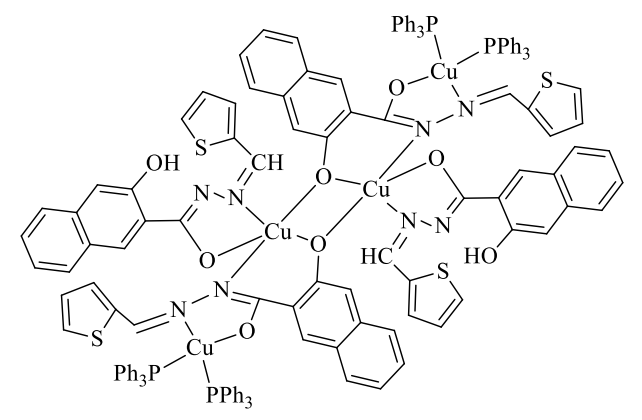

Fig. 25. Copper(I/II) complex of 3-hydroxy naphthalene2-carboxylic acid thiophen-2-ylmethylene hydrazide (Anu et al., 2019)

\section{CONCLUSION}

Copper(I) complexes have been found to dissociate partially by generating an empty site on $\mathrm{Cu}^{+}$ions that can facilitate the complexes to interact with the biological target. Copper(I) ion, being stabilized by phosphane and $\mathrm{N}, \mathrm{N}$-diimine systems form many complexes with higher anticancer potency, lesser toxicity, and lower drug resistance activity toward various cancer cell lines than that of their corresponding copper(II) complexes as well as standard cisplatin drug. The designation of copper(I) molecules with the modification in N,N-diimine systems by the organic moiety with anticancer potency may bring revolution in the synthesis of anticancer drugs with significant inhibitory activity.

\section{ACKNOWLEDGEMENT}

The authors sincerely acknowledge the Nepal Academy of Science and Technology (NAST), Nepal for providing Ph. D. fellowship (2015/2016 AD) to NKS.

\section{CONFLICT OF INTEREST}

The authors declare no conflict of interest.

\section{REFERENCES}

Alvarez, N., Noble, C., Torre, M. H., Kremer, E., Ellena, J., Peres de Araujo, M., Costa-Filho, A. J., Mendes, L. F., Kramer, M. G., \& Facchin, G. (2017). Synthesis, structural characterization, and cytotoxic activity against tumor cells of heteroleptic copper (I) complexes with aromatic diimines and phosphines. Inorganica Chimica Acta, 466, 559-564.

Anu, D., Naveen, P., VijayaPandiyan, B., Frampton, C. S., \& Kaveri, M. V. (2019). An unexpected mixed valence tetranuclear copper (I/II) complex: Synthesis, structural characterization, DNA/protein binding, antioxidant and anticancer properties. Polyhedron, 167, 137-150.

Bravo, C., Robalo, M. P., Marques, F., Fernandes, A. R., Sequeira, D. A., Minas da Piedade, M. F., Garcia, M. H., Villa de Brito, M. J, \& Morais, T. S. (2019). First heterobimetallic $\mathrm{Cu}(\mathrm{I})$-dppf complexes designed for anticancer applications: synthesis, structural characterization and cytotoxicity. New Journal of Chemistry. https://doi.org/10.1039/c9nj02068c

Bykowska, A., Komarnicka, U. K., Jeżowska-Bojczuk, M., \& Kyzioł, A. (2018). $\mathrm{Cu}(\mathrm{I})$ and $\mathrm{Cu}(\mathrm{II})$ complexes with phosphine derivatives of fluoroquinolone antibiotics - a comparative study on the cytotoxic mode of action. Journal of Inorganic Biochemistry, 181, 1-10.

Daniel, K. G., Chen, D., Orlu, S., Cui, Q. C., Miller, F. R., \& Dou, Q. P. (2005). Clioquinol and pyrrolidine dithiocarbamate complex with copper to form proteasome inhibitors and apoptosis inducers in human breast cancer cells. Breast Cancer Research, 7(6). https://doi.org/10.1186/bcr1322

Gandin, V., Ceresa, C., Esposito, G., Indraccolo, S., Porchia, M., Tisato, F., Santini, C., Pellei, M., \& Marzano, C. (2017). Therapeutic potential of the phosphino $\mathrm{Cu}(\mathrm{I})$ complex (HydroCuP) in the treatment of solid tumors. Scientific Reports, 7(1). https://doi.org/10.1038/s41598-017-13698-1

Gandin, V., Trenti, A., Porchia, M., Tisato, F., Giorgetti, M., Zanusso, I., Trevisi, L., \& Marzano, C. (2015). Homoleptic phosphino copper(I) complexes with in vitro and in vivo dual cytotoxic and antiangiogenic activity. Metallomics, 7(11), 1497-1507.

Gonzalez-Ballesteros, N., Perez-Alvarez, D., Henriques, M. S. C., Nascimento, B. F. O., Laranjo, M., Santos, K., Casalta-Lopes, J., Abrantes, A. M., Botelho, M. F., Pineiro, M., Paixao, J. A., \& RodriguezArguelles, M. C. (2015). Copper(I) complexes of methyl 4-aryl-6-methyl-3,4-dihydropyrimidine2(1H)-thione-5-carboxylates. Synthesis, characterization and activity in human breast cancer cells. Inorganica Chimica Acta, 438, 160-167.

Gonzalez-Ballesteros, N., Perez-Alvarez, D., RodriguezArguelles, M. C., Henriques, M. S. C., Paixao, J. A., \& Prado-Lopez, S. (2016). Synthesis, spectral characterization and X-ray crystallographic study of 
new copper(I) complexes. Antitumor activity in colon cancer. Polyhedron, 119, 112-119.

Gunasekaran, N., Ramesh, P., Ponnuswamy, M. N. G., \& Karvembu, R. (2011). Monodentate coordination of $\mathrm{N}$-[di(phenyl/ethyl)carbamothioyl]benzamide ligands: synthesis, crystal structure and catalytic oxidation property of $\mathrm{Cu}(\mathrm{I})$ complexes. Dalton Transactions, 40(46), 12519. https://doi.org/10.1039/c1dt10628g

Jansson, P. J., Sharpe, P. C., Bernhardt, P. V., \& Richardson, D. R. (2010). Novel thiosemicarbazones of the ApT and DpT series and their copper complexes: Identification of pronounced redox activity and characterization of their antitumor activity. Journal of Medicinal Chemistry, 53(15), 5759-5769.

Kokina, T. E., Glinskaya, L. A., Sheludyakova, L. A., Eremina, Y. A., Klyushova, L. S., Komarov, V. Y., Piryazev, D. A., Tkachev, A. V., \& Larionov, S. V. (2019). Synthesis, structure, and cytotoxicity of complexes of zinc(II), palladium(II), and copper(I) chlorides with (-)-camphor thiosemicarbazone. Polyhedron.

https://doi.org/10.1016/j.poly.2019.02.020

Komarnicka, U. K., Kozieł, S., Starosta, R., \& Kyzioł, A. (2018). Selective $\mathrm{Cu}(\mathrm{I})$ complex with phosphinepeptide ( SarGly ) conjugate contra breast cancer: Synthesis, spectroscopic characterization and insight into cytotoxic action. Journal of Inorganic Biochemistry, 186, 162-175.

Komarnicka, U. K., Starosta, R., Kyzioł, A., Płotek, M., Puchalska, M., \& Jeżowska-Bojczuk, M. (2016a). New copper(I) complexes bearing lomefloxacin motif: Spectroscopic properties, in vitro cytotoxicity and interactions with DNA and human serum albumin. Journal of Inorganic Biochemistry, 165, 25-35.

Komarnicka, U. K., Starosta, R., Płotek, M., de Almeida, R. F. M., Jeżowska-Bojczuk, M., \& Kyzioł, A. (2016b). Copper(I) complexes with phosphine derived from sparfloxacin. Part II: a first insight into the cytotoxic action mode. Dalton Transactions, 45(12), 5052-5063.

Lee, R. F., \& Steinert, S. (2003). Use of the single cell gel electrophoresis/comet assay for detecting DNA damage in aquatic (marine and freshwater) animals. Mutation Research/Reviews in Mutation Research, 544(1), 43-64.

Liu, Rui-Xue, Luo, Ru-Yi, Tang, Meng-Ting, Liu, YanCheng, Chen, Zhen-Feng, \& Liang, Hong. (2021). The first copper(I) complex of anthrahydrazone with potential ROS scavenging activity showed significant in vitro anticancer activity by inducing apoptosis and autophagy, Journal of Inorganic Biochemistry, 111390. https://doi.org/10.1016/j.jinorgbio.2021.111390

Lopes, J., Alves, D., Morais, T. S., Costa, P. J., Piedade, M. F. M., Marques, F., Maria J. Villa de Brito, Villa de Brito, M. J. \& Helena Garcia, M. (2017). New copper(I) and heteronuclear copper(I)-ruthenium(II) complexes: Synthesis, structural characterization and cytotoxicity. Journal of Inorganic Biochemistry, 169, 68-78.

Lopes, U. G., Erhardt, P., Yao, R., \& Cooper, G. M. (1997). p53-dependent Induction of Apoptosis by Proteasome Inhibitors. Journal of Biological Chemistry, 272(20), 12893-12896.

Machado, J. F., Sequeira, D. A., Marques, F. M., Minas da Piedade, M. F., Brito, M. V., Garcia, M. H., Fernandes, A. R., \& Morais, T. S. (2020). New copper(I) complexes selective for prostate cancer cells. Dalton Transactions, 21 pages. https://doi.org/10.1039/d0dt02157a

Mahendiran, D., Amuthakala, S., Bhuvanesh, N. S. P., Kumar, R. S., \& Rahiman, A. K. (2018a). Copper complexes as prospective anticancer agents: in vitro and in vivo evaluation, selective targeting of cancer cells by DNA damage and $\mathrm{S}$ phase arrest. RSC Advances, 8(30), 16973-16990.

Mahendiran, D., Pravin, N., Bhuvanesh, N. S. P., Kumar, R. S., Viswanathan, V., Velmurugan, D., \& Rahiman, A. $\mathrm{K}$. (2018b). Bis(thiosemicarbazone)copper(I) complexes as prospective therapeutic agents: Interaction with DNA/BSA molecules, and in vitro and in vivo anti-proliferative activities. Chemistry Select, 3(25), 7100-7111.

Marin-Hernandez, A., Gracia-Mora, I., Ruiz-Ramirez, L., \& Moreno-Sanchez, R. (2003). Toxic effects of copper-based antineoplastic drugs (Casiopeinas ${ }^{\circledR}$ ) on mitochondrial functions. Biochemical Pharmacology, 65(12), 1979-1989.

Marzano, C., Pellei, M., Alidori, S., Brossa, A., Lobbia, G. G., Tisato, F., \& Santini, C. (2006). New copper(I) phosphane complexes of dihydridobis(3nitro-1,2,4-triazolyl)borate ligand showing cytotoxic activity. Journal of Inorganic Biochemistry, 100(2), 299-304.

Marzano, C., Pellei, M., Tisato, F., \& Santini, C. (2009). Copper complexes as anticancer agents. Anti-Cancer Agents in Medicinal Chemistry, 9(2), 185-211.

Milani, N. C., Maghsoud, Y., Hosseini, M., Babaei, A., Rahmani, H., Roe, S. M., \& Gholivand, K. (2020). A 
new class of copper(I) complexes with iminecontaining chelators which show potent anticancer activity. Applied Organometallic Chemistry, 2020, e5526, 21 pages. https://doi.org/10.1002/aoc.5526

Miller III, M. C., Stineman, C. N., Vance, J. R., West, D. X. \& Hall, I. H. (1999). Multiple mechanisms for cytotoxicity induced by copper(II) complexes of 2 acetylpyrazine-N-substituted thiosemicarbazones. Applied Organometallic Chemistry, 13(1), 9-19.

Morais, T. S., Jousseaume, Y., M. Piedade, M. F., RomaRodrigues, C., Fernandes, A. R., Marques, F., Villa de Brito, M. J., \& Garcia, M. H. (2018). Important cytotoxic and cytostatic effects of new copper(I)phosphane compounds with N,N, N,O and N,S bidentate ligands. Dalton Transactions, 47(23), 7819-7829.

Mosmann, T. (1983). Rapid colorimetric assay for cellular growth and survival: Application to proliferation and cytotoxicity assays. Journal of Immunological Methods, 65(1-2), 55-63.

Pandey, S. K., Pratap, S., Pokharia, S., Mishra, H., Marverti, G., Kaur, M., \& Jasinski, J. P. (2019b). Copper (I) complexes based on novel N, N'-disubstituted thiocarbamides: Synthesis, spectroscopic, in vitro cytotoxicity, DNA damage and G0/G1 cell cycle arrest studies. Inorganica Chimica Acta, 491, 105-117.

Pandey, S. K., Singh, D. P., Marverti, G., Butcher, R. J., \& Pratap, S. (2018). Monodentate Coordination of $\mathrm{N}$, N'-Disubstituted thiocarbamide ligands: Syntheses, structural analyses, In vitro cytotoxicity and DNA damage studies of $\mathrm{Cu}(\mathrm{I})$ complexes. Chemistry Select, 3(13), 3675-3679.

Pandey, S. K., Singh, D. P., Pratap, S., Marverti, G., \& Butcher, R. J. (2019a). Copper(I) complexes of N(2/4 methoxy/2-chloro-4-nitro)phenyl- $\mathrm{N}^{\prime}$ (methoxycarbonyl)thiocarbamides as potential anticancer agents: Synthesis, crystal structure, in vitro cytotoxicity and DNA damage studies. Polyhedron, 170, 431-439.

Papazoglou, I., Cox, P. J., Hatzidimitriou, A. G., Kokotidou, C., Choli-Papadopoulou, T., \& Aslanidis, P. (2014). Copper(I) halide complexes of 5-carbethoxy-2-thiouracil: Synthesis, structure and in vitro cytotoxicity. European Journal of Medicinal Chemistry, 78, 383-391.

Pellei, M., Bagnarelli, L., Luciani, L., Del Bello, F., Giorgioni, G., Piergentili, A., Quaglia, W., De Franco, M., Gandin, V., Marzano, C., \& Santini, C. (2020). Synthesis and cytotoxic activity evaluation of new $\mathrm{Cu}(\mathrm{I})$ complexes of bis(pyrazol-1-yl) acetate ligands functionalized with an NMDA receptor antagonist. International Journal of Molecular Sciences, 21(7), 2616.

Pellei, M., Gandin, V., Cimarelli, C., Quaglia, W., Mosca, N., Bagnarelli, L., Marzano, C., \& Santini, C. (2018). Syntheses and biological studies of nitroimidazole conjugated heteroscorpionate ligands and related $\mathrm{Cu}(\mathrm{I})$ and $\mathrm{Cu}(\mathrm{II})$ complexes. Journal of Inorganic Biochemistry, 187, 33-40.

Porchia, M., Benetollo, F., Refosco, F., Tisato, F., Marzano, C., \& Gandin, V. (2009). Synthesis and structural characterization of copper(I) complexes bearing N-methyl-1,3,5-triaza-7-phosphaadamantane (mPTA). Journal of Inorganic Biochemistry, 103(12), 1644-1651.

Puig, S., \& Thiele, D. J. (2002). Molecular mechanisms of copper uptake and distribution. Current Opinion in Chemical Biology, 6(2), 171-180.

Puig, S., Lee, J., Lau, M., \& Thiele, D. J. (2002). Biochemical and genetic analyses of yeast and human high affinity copper transporters suggest a conserved mechanism for copper uptake. Journal of Biological Chemistry, 277(29), 26021-26030.

Saeed, S., Rashid, N., Jones, P. G., Ali, M., \& Hussain, R. (2010). Synthesis, characterization and biological evaluation of some thiourea derivatives bearing benzothiazole moiety as potential antimicrobial and anticancer agents. European Journal of Medicinal Chemistry, 45(4), 1323-1331.

Santini, C., Pellei, M., Gandin, V., Porchia, M., Tisato, F., \& Marzano, C. (2013). Advances in copper complexes as anticancer agents. Chemical Reviews, 114(1), 815-862.

Saswati, Chakraborty A., Dash, S. P., Panda A. K., Acharyya R., Biswas, Mukhopadhyay, S., Bhutia, S. K., Crochet, A., Patil, Y. P., Nethaji, M., \& Dinda, R. (2015). Synthesis, $\mathrm{X}$-ray structure and in vitro cytotoxicity studies of $\mathrm{Cu}(\mathrm{I} / \mathrm{II})$ complexes of thiosemicarbazone: special emphasis on their interactions with DNA. Dalton Transactions, 44(13), 6140-6157.

Sathiyaraj, S., Sampath, K., Butcher, R. J., Pallepogu, R., \& Jayabalakrishnan, C. (2013). Designing, structural elucidation, comparison of DNA binding, cleavage, radical scavenging activity and anticancer activity of copper(I) complex with 5-dimethyl-2-phenyl-4[(pyridin-2-ylmethylene)-amino]-1,2-dihydropyrazol-3-one Schiff base ligand. European Journal of Medicinal Chemistry, 64, 81-89.

Shao, J., Ma, Z. -Y., Li, A., Liu, Y. -H., Xie, C. -Z., Qiang, Z. $\quad$ Y., \& $\quad \mathrm{Xu}, \quad$ J. $\quad-Y$. 
Anticancer potency of copper(I) complexes against a range cancer cell lines: a review

(2014). Thiosemicarbazone $\mathrm{Cu}(\mathrm{II})$ and $\mathrm{Zn}(\mathrm{II})$ complexes as potential anticancer agents: Syntheses, crystal structure, DNA cleavage, cytotoxicity and apoptosis induction activity. Journal of Inorganic Biochemistry, 136, 13-23.

Singh, D. P., Pratap, S., Pandey, S. K., Butcher, R. J., \& Marverti, G. (2015). N-(naphthyl)-N'-(methoxy carbonyl)thiocarbamide and its $\mathrm{Cu}(\mathrm{I})$ complex: synthesis, spectroscopic, X-ray, DFT and in vitro cytotoxicity study. Journal of Coordination Chemistry, 68(2), 261-276.

Singh, N. K., Shrestha, S., Shahi, N., Choudhary, R. K., Kumbhar, A. A., Pokharel, Y. R., \& Yadav, P. N.(2021a). Enhancement of anticancer activity of N(4)1-(2-pyridyl)piperazinyl 5-nitroisatin thiosemicarbazone on chelation with copper(II). Asian Journal of Chemistry, 33(3) 557-564.

Singh, N. K., Shrestha, S., Shahi, N., Choudhary, R. K., Kumbhar, A. A., Pokharel, Y. R., \& Yadav, P. N. (2021b). Anticancer potential of N(4)substituted 5nitroisatin thiosemicarbazones and their copper(II) complexes. Rasayan Journal of Chemistry, 14(3) (manuscript accepted).
Singh, N. K., Yadav, P. N., Kumbhar, A. A., \& Pokhrel, Y. R. (2020). Anticancer potency of copper(II) complexes of thiosemicarbazones. Journal of Inorganic Biochemistry, 111134. https://doi.org/10.1016/j.jinorgbio.2020.111 134

Stepanenko, A. A., \& Dmitrenko, V. V. (2015). Pitfalls of the MTT assay: Direct and off-target effects of inhibitors can result in over/underestimation of cell viability. Gene, 574(2), 193-203.

Tabrizi, L., \& Chiniforoshan, H. (2017). Synthesis and C$\mathrm{H}$ activation reactions of cyclometalated copper(i) complexes with NCN pincer and 1,3,5-triaza-7phosphaadamantane derivatives: in vitro antimicrobial and cytotoxic activity. New Journal of Chemistry, 41(19), 10972-10984.

Xian, L., Wei, T. -B., \& Zhang, Y. -M. (2004). Synthesis and crystal structure of bis(N-o-methylphenyl-N'ethoxycarbonylthiourea) copper(I) chloride. Journal of Coordination Chemistry, 57(6), 453-457. 